\title{
PENGGUNAAN MODEL PEMBELAJARAN EXAMPLES NON EXAMPLES BERBANTUAN MEDIA GAMBAR UNTUK MENINGKATKAN KEMAMPUAN BAHASA KEDUA DAN HASIL BELAJAR PADA SISWA KELAS I MIN RUMPIANG
}

\author{
Rahidatul Laila Agustina dan Novia Winda \\ STKIP-PGRI Banjarmasin \\ Jln. Sultan Adam Kompleks H. Iyus, No. 18 RT. 23 Banjarmasin, \\ Kode Pos 70121. \\ e-mail: lailarahidatul@yahoo.com
}

\begin{abstract}
Abstrak
Penelitian ini bertujuan untuk mengetahui penggunaan model pembelajaran examples non examples berbantuan media gambar dalam meningkatkan kemampuan bahasa kedua dan hasil belajar Bahasa Indonesia siswa kelas I MIN Rumpiang Kecamatan Beruntung Baru Kabupaten Banjar.

Metode yang digunakan dalam penelitian ini adalah penelitian tindakan kelas yang dilaksanakan dalam dua siklus penelitian, setiap siklus terdiri dari 2 kali pertemuan. Subyek penelitian ini adalah siswa kelas I MIN Rumpiang pada semester ganjil tahun ajaran 2015/2016, dengan jumlah siswa 17orang. Pengumpulan data dalam penelitian ini diperoleh melalui teknik observasi dan tes tertulis, sedangkan teknik analisis data yang digunakan adalah rata-rata dan persentase.

Hasil penelitian ini diperoleh: (1) Penggunaan model pembelajaran examples non examples berbantuan media gambar dapat meningkatkan pencapaian hasil belajar siswa, pada siklus I dengan nilai rata-rata 69,70 dan ketuntasan klasikal $50 \%$ mengalami peningkatan pada siklus II dengan nilai rata-rata 76,76 dengan ketuntasan klasikal 82,35 \%. (2) Aktivitas guru dan siswa terhadap pembelajaran bahasa dengan penggunaan model pembelajaran examples non examples berbantuan media gambar juga menunjukkan peningkatan. Hal ini dapat diihat dari perolehan nilai aktivitas belajar siswa, pada siklus I dengan rata-rata 58,75 dalam kategori kurang aktif mengalami peningkatan pada siklus II dengan rata-rata 82,5 dalam kategori aktif. Begitupun dengan aktivitas guru yang dilihat dari hasil observasi pada siklus I dengan persentase 56,6 \% dalam kategori cukup meningkat pada siklus II dengan persentase $76,6 \%$ dalam kategori baik. (3) Hasil respon siswa terhadap pembelajaran yang disajikan guru dari hasil angket yang dijawab siswa menunjukkan bahwa siswa menyenangi dan sangat termotivasi terhadap model pembelajaran examples non examples berbantuan media gambardalam pembelajaran bahasa.
\end{abstract}

Kata Kunci: Examples non examples, media gambar, kemampuan bahasa kedua, hasil belajar

\section{Pendahuluan}

Proses belajar mengajar merupakan suatu sistem yang terdiri dari komponen-komponen saling terkait, antara lain tujuan pembelajaran, materi pelajaran, metode dan media pembelajaran, serta evaluasi hasil belajar. Metode mengajar merupakan salah satu komponen proses pembelajaran yang berperan penting dalam menciptakan interaksi dan komunikasi penyajian materi pelajaran hingga tercapainya tujuan pembelajaran yang ditetapkan. Arti penting metode mengajar ini 
ditunjukkan pada kemudahan dan kesanggupan siswa menerima materi pelajaran yang diberikan guru sehingga kemampuan menguasai setiap kelompok bahasan dapat tercapai optimal.

Peroses belajar mengajar dilakukan berorientasi pilar 4 belajar. Pertama guru memfasilitasi siswa belajar memahami (learning to know). Kedua guru membimbing siswa belajar melaksanakan dan berbuat secara efektif (learning to do). Ketiga guru mendorong siswa untuk belajar menemukan jati diri (learning to be). Keempat guru mengarahkan siswa untuk belajar hidup bersama (learning to live together). Semua itu dilakukan melalui proses pembelajaran yang aktif, kreatif, efektif, dan menyenangkan (Depdiknas, 2006:7).

Kenyataan yang dihadapi di kelas I MIN Rumpiang untuk meningkatkankemampuan bahasa kedua masih belum optimal. Guru belum menggunakan metode mengajar yang mampu membuat anak aktif belajar sehingga dalam menerima informasi siswa cenderung pasif. Selain itu media pembelajaran yang digunakan tidak maksimal dan belum relevan terhadap metode yang dipilih.Rendahnya hasil belajar siswa memahami bahasa kedua ini disebabkan oleh guru hanya menggunakan metode ceramah. Guru juga hanya terpaku pada penggunaan media papan tulis. Siswa hanya mendengarkan dan mencatat penjelasan guru. Siswa akhirnya kesulitan untuk menunjukkan unsur-unsur bangun datar secara tepat dan benar.

Akibatnya yang dirasakan dari rendahnya hasil belajar siswa pada kemampuan bahasa kedua ini terlihat dari sikap kebingungan siswa dalam penggunaan bahasa kedua tersebut. Nilai hasil belajar siswa kelas I MIN Rumpiang Banjarmasin pada mata pelajaran Bahasa Indonesia adalah 50 di bawah 65 standar ketuntasan balajar minimal. Siswa yang mendapat nilai 65 atau lebih hanya 50\%. Sedangkan kriteria ketuntasan minimal yang ditetapkan sekolah adalah siswa yang mendapat nilai 65 atau lebih minimal 90\% dari jumlah siswa di kelas I MIN Rumpiang.

Berdasarkan temuan di atas, dapat dinyatakan bahwa tindakan kelas yang diperlukan adalah merubah strategi pembelajaran dengan metode yang mengaktifkan dan menyenangkan siswa. Dalam pembelajaran siswa yang aktif bukan guru yang aktif. Guru hanyalah memberikan bimbingan, dorongan, memfasilitasi, dan membantu kesulitan siswa. Supaya siswa aktif dan kreatif maka guru perlu menggunakan model pembelajaran yang tepat.

Sanjaya (2010:132) mengemukakan bahwa proses pembelajaran adalah proses yang dapat mengembangkan seluruh potensi siswa. Seluruh potensi itu hanya mungkin dapat berkembang manakala siswa terbebas dari rasa takut, dan menegangkan. Oleh karena itu, perlu diupayakan agar proses pembelajaran merupakan proses yang menyenangkan. Proses pembelajaran yang menyenangkan bisa dilakukan, pertama dengan menata ruangan yang apik dan menarik, kedua melalui pengelolaan pembelajaran yang hidup dan bervariasi.

Belajar bukanlah menghafal sejumlah fakta-fakta atau informasi. Belajar adalah berbuat, memperoleh pengalaman tertentu sesuai dengan tujuan yang diharapkan. Karena itu, strategi 
pembelajaran harus dapat mendorong aktivitas siswa. Aktivitas siswa tidak dimaksudkan aktivitas fisik, akan tetapi juga meliputi aktivitas yang bersifat psikis seperti mental. Guru sering lupa dengan hal ini. Banyak guru yang terkecoh oleh sikap siswa pura-pura aktif padahal sebenarnya tidak.

Model pembelajaran examples non example merupakan model pembelajaran yang dapat membuat siswa belajar aktif, mandiri, dan menyenangkan. Dalam model ini guru memberikan stimulan dengan gambar-gambar. Melalui gambar-gambar itulah siswa mempelajari konsep yang ingin dikuasai mereka. Proses pembelajaran adalah proses yang menantang siswa untuk mengembangkan kemampuan berpikir, yakni merangsang kerja otak secara maksimal. Kemampuan tersebut dapat ditumbuhkan dengan cara mengembangkan rasa ingin tahu siswa melalui kegiatan mencoba-coba, berpikir secara intuitif atau bereksploirasi (Sanjaya, 2006:132).Model pembelajaran ini cocok untuk menyampaikan materi yang sifatnya prosedural atau langkah-langkah melakukan sesuatu secara bertahap. Langkah-langkah itu meliputi penyajian informasi kompetensi, mendemonstrasikan pengetahuan dan keterampilan, membimbing pelatihan-penerapan, mengecek pemahaman dan balikan, penyimpulan, evaluasi, dan refleksi (Suyatno, 2009:127).

Sejalan dengan asumsi tersebut (Daryanto, 2009:208) menegaskan proses pembelajaran pada satuan pendidikan diselenggarakan secara interaktif, inspiratif, menyenangkan, menantang, memotivasi peserta didik untuk berpartisipasi aktif, serta memberikan ruang yang cukup untuk bagi prakarsa, kreativitas, dan kemandirian sesuai dengan bakat, minat, dan perkembangan fisik dan psikologis peserta didik. Motivasi adalah aspek yang sangat penting untuk membelajarkan siswa. Tanpa adanya motivasi, tidak mungkin siswa memiliki kemauan untuk belajar. Oleh karena itu, membangkitkan motivasi merupakan salah satu peran dan tugas guru dalam setiap pembelajaran. Motivasi dapat diartikan sebagai dorongan yang memungkinkan siswa untuk bertindak atau melakukan sesuatu. Dorongan itu hanya mungkin muncul dalam diri siswa manakala siswa membutuhkan (need). Sswa yang merasa butuh akan bergerak dengan sendirinya untuk memenuhi kebutuhannya.

Berdasarkan pemikiran di atas, perlu dilaksanakan pembelajaran dengan menerapkan model pembelajaran examples non examples berbantuan dengan media gambar. Penerapan model tersebut dilaksanakan melalui penelitian tindakan kelas untuk meningkatkan hasil belajar siswa.Belajar adalah usaha sadar yang dilakukan oleh individu dalam perubahan tingkah laku baik melalui latihan dan pengalaman yang menyangkut aspek-aspek kognitif, afektif, dan psikomotorik untuk memperoleh tujuan tertentu. Pada prinsipnya belajar adalah berbuat. Tidak ada belajar kalau tidak ada aktivitas. Tanpa aktivitas, proses belajar tidak mungkin berlangsung dengan baik. Paul B. Diedrich dalam Sardiman menggolongkan kegiatan siswa sebagai berikut: 1) Visual activities, 2) Oral Activities, 3) Listening activities, 4) Writing activities, 5) Drawing activities, 6) Motor activities, 7) Mental activities, dan 8) Emotional activities (Sardiman 2011:95-101). 
Hasil belajar merupakan perubahan perilaku secara keseluruhan bukan hanya salah satu aspek potensi kemanusiaan saja (Suprijono, 2009:7). Menurut Purwanto (2013:46), hasil belajar pada hakikatnya adalah perubahan perilaku akibat belajar. Perubahan perilaku disebabkan karena dia mencapai penguasaan atas sejumlah bahan yang diberikan dalam proses belajar mengajar. Pencapaian itu didasarkan atas tujuan pengejaran yang telah ditetapkan. Bloom (1956) dalam (Poerwanti, Widodo, Masduki, Pantiwati, Rofieq, dkk. 2009:1-23-1-30) mengklasifikasikan hasil belajar ke dalam tiga ranah yaitu: ranah kognitif, ranah afektif dan ranah psikomotorik

Pembelajaran harus disesuaikan dengan minat anak. Anak harus didorong untuk melakukan eksplorasi dan belajar sendiri. Pembelajaran merupakan suatu kegiatan yang melibatkan seseorang dalamupaya memperoleh pengetahuan, ketrampilan dan nilai-nilai positif dengan memanfaatkan berbagai sumber untuk belajar.Pembelajaran Bahasa Indonesia diarahkan untuk meningkatkan kemampuan berkomunikasi Bahasa Indonesia lisan dan tulis peserta didik, serta menumbuhkan apresiasi terhadap karya sastra Indonesia dan karya intelektual bangsa sendiri (Gipayana, 2006:145). Pembelajaran Bahasa Indonesia di SD/MI memiliki nilai penting, karena pada jenjang pendidikan inilah pertama kalinya pengajaran bahasa Indonesia dilaksanakan secara berencana dan terarah.

Bahasa merupakan suatu sistem komunikasi yang mempergunakan simbol-simbol yang bersifat arbitrer/ manasuka, yang dapat diperkuat dengan gerak-gerik badaniah yang nyata. Simbol adalah tanda yang diberikan makna tertentu, yaitu mengacu pada sesuatu yang dapat diserap oleh pancaindera. Secara umum, bahasa itu mempunyai suatu fungsi tertentu, yaitu (1) alat untuk menyatakan ekspresi diri, menyatakan secara terbuka segala sesuatu yang tersirat di dalam dada kita, (2) alat komunikasi, merupakan saluran perumusan maksud kita yang memungkinkan kita menciptakan kerja sama, (3) alat mengadakan integrasi dan adaptasi sosial, bahasa merupakan alat yang memungkinkan tiap orang untuk merasa dirinya terikat dengan kelompok sosial yang dimasukinya, serta dapat melakukan semua kegiatan kemasyarakatan dengan menghindari sejauh mungkin bentrokan-bentrokan untuk memperoleh efisiensi yang setinggi-tingginya, (4) alat mengadakan kontrol social (Mularsih, 2015). Keterampilan berbahasa meliputi empat aspek yaitu: menyimak, berbicara, membaca dan menulis (Nugraheni, 2012:74).

Mengingat pentingnya pembelajaran bahasa Indonesia terkait dengan penggunaan bahasa kedua yakni bahasa Indonesia, maka sangat diperlukan peran penting guru dalam memilih teknik pembelajaran yang disenangi siswa SD/MI serta dapat membangkitkan motivasi belajarnya sehingga mereka menerapkan bahasa keduaya dalam situasi yang menyenangkan. Cerita akan lebih menarik apabila disampaikan dengan menggunakan media gambar. Media gambar dikenal namun masih jarang dimanfaatkan, khususnya dalam pembelajaran Bahasa Indonesia di SD. Media sangat diperlukan sebagai alat untuk membantu seorang guru dalam memberikan suatu penjelasan, baik itu 
bersifat kongkrit maupun abstrak, akan tetapi dalam penggunaan media ini diperlukan suatu keterampilan, kekreatifan yang dituntut pada seorang guru untuk menggunakan berbagai media terutama sarana dan prasarana yang dimiliki oleh sekolah serta pemanfaatan lingkungan sebagai media dalam proses pembelajaran di sekolah. Dengan penyajian materi menggunakan media gambar diharapkan penggunaan bahasa kedua siswa dapat meningkat, sehingga menumbuhkan kepercayaan diri menggunakan bahasa kedua yakni bahasa Indonesia.

\section{Metode Penelitian}

Jenis penelitian ini adalah Penelitian Tindakan Kelas (PTK). Penelitian tindakan kelas merupakan suatu penelitian bersiklus yang dilakukan oleh guru, yang berdasar pada permasalahan rill yang ditemui dikelasnya, melalui langkah-langkah merancang, melaksanakan dan merefleksikan tindakan secara kolaboatif, partisipatif dan reflektif mandiri dengan tujuan untuk memperbaiki kualitas pembelajaran (Soekamto, dkk, 2009:6).Tujuan utama PTK adalah untuk memecahkan permasalahan nyata yang terjadi dikelas dan meningkatkan kegiatan nyata guru dalam pengembangan profesinya.

Lokasi penelitian adalah di MIN Rumpiang Kecamatan Beruntung Baru Kabupaten Banjar yang beralamat di Jl. Arsyadiyah Rumpiang RT. 001 RW. 001 Kecamatan Beruntung Baru Kabupaten Banjar Provinsi Kalimantan Selatan kode pos 70655. Subjek dalam penelitian Tindakan Kelas ini adalah siswa kelas I yang berjumlah 17 orang siswa yang terdiri dari 12 orang siswa lakilaki dan 5 orang siswa perempuan pada semester I (ganjil) tahun ajaran 2015/2016. Alasan pengambilan subjek penelitian ini karena peneliti merasa apa yang dicapai oleh sekolah tersebut masih belum optimal terutama dalam hal pembelajaran sehingga peneliti ingin meningkatkan kualitas pembelajaran dan hasil belajar siswa di MIN Rumpiang Kecamatan Beruntung Baru agar mampu bersaing dalam hal kualitas dengan sekolah di perkotaan yang mempunyai sarana dan prasarana yang lengkap dan lebih memadai.

Model PTK yang dilakukan dalam penelitian ini adalah PTK kolaboratif. Model ini dipandang tepat karena masalah yang diangkat dalam penelitian ini adalah masalah yang terjadi di kelas I MIN Rumpiang. Dalam PTK ini peneliti sebagai pengamat partisipan dan kolaborasi dengan guru kelas I MIN Rumpiang. Dalam penelitian ini, peneliti bertindak sebagai instrumen kunci karena peneliti yang merancang, mengumpulkan data, menganalisis data, menarik kesimpulan, dan membuat laporan, sedangkan pelaksanaan pengajaran diserahkan pada guru kelas I MIN Rumpiang.

Sesuai dengan jenis penelitian yang dipilih yaitu penelitian tindakan kelas, maka penelitian ini menggunakan model penelitian tindakan dari (Arikunto, 2010:16) yaitu berbentuk spiral dari siklus yang satu ke siklus yang berikut. Setiap siklus memiliki planning (rencana), action (pelaksanaan), observasi (pengamatan) dan reflection (refleksi). Langkah pada siklus berikutnya 
adalah perencanaan sudah direvisi, pelaksanaan, pengamatan, dan refleksi. Sebelum masuk pada siklus 1 dilakukan tindakan pendahuluan yang berupa identifikasi permasalahan (observasi).

Data yang diperlukan dalam penelitian adalah datatentang aktivitas guru dan siswa kelas IV SDN Kampung Baru, dan data hasil belajar siswa untuk mengetahuipeningkatan hasil belajar siswa. Instrumen yangdigunakan dalam penelitian ini adalah lembar observasiaktivitas guru dan siswa, dan tes hasil belajar. Analisis inidihitung dengan menggunakan deskriptif kualitatif dankuantitatif.

\section{Hasil Dan Pembahasan}

Berdasarkan hasil pengamatan yang dilakukan peneliti terhadap kegiatan siswa dalam proses pembelajaran baik siklus I maupun siklus II terlihat bahwa siswa aktif dalam kegiatan pembelajaran menulis deskripsi melalui penggunaan model pembelajaran examples non examples berbantuan media gambar. Kemampuan berbahasa kedua siswa yang ditunjukkan dari hasil pengamatan selama proses pembelajaran berlangsung, terjadi peningkatan secara signifikan dari siklus I hingga siklus II. Hal ini dapat dilihat dari rata-rata nilai siswa pada siklus I yaitu hanya 69,70 dengan ketuntasan kasikal hanya $50 \%$ meningkat pada siklus II dengan rata-rata nilai siswa 76,76 dengan ketuntasan klasikal 82,35 \%. Berdasarkan data pencapaian hasil belajar tersebut, indikator keberhasilan sudah tercapai artinya target $80 \%$ penguasaan secara klasikal sudah terpenuhi.

Dari data hasil nilai yang diperoleh pada kegiatan siklus I dan siklus II dapat diuraikan perbandingan hasil belajar siswa sebagai berikut:

Tabel 1 Perbandingan Hasil Belajar Siklus I dan siklus II

\begin{tabular}{|c|c|c|}
\hline Kegiatan & Nilai rata-rata & Ketuntasan Klasikal \\
\hline Siklus I & 69,70 & $50 \%$ \\
\hline Siklus II & 76,76 & $82,35 \%$ \\
\hline
\end{tabular}

Dilihat dari rata-rata nilai tiap pertemuan ada peningkatan yang sangat signifikan, dan telah mencapai tingkat ketuntasan secara klasikal karena dilihat dari presentase ketuntasan sudah berada diatas standar ketuntasan minimal. Adapun perbandingan persentase nilai hasil siswa dapat dilihat pada diagram berikut ini: 


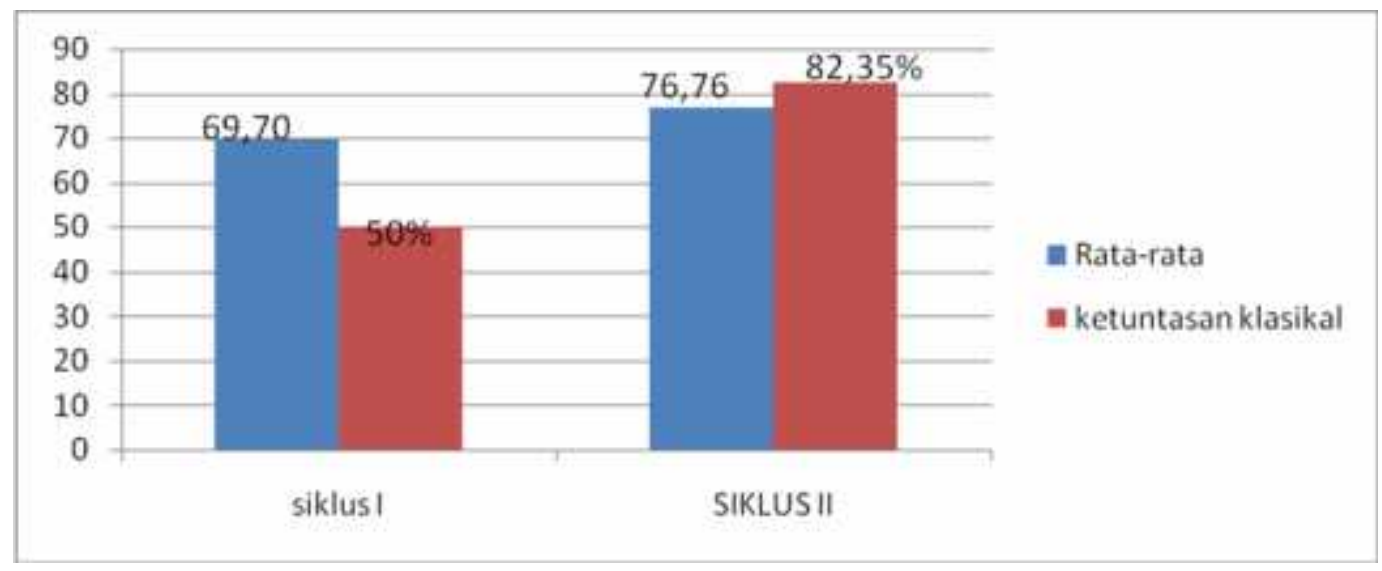

Diagram 1 Perbandingan Hasil Belajar Siklus I dan siklus II

Berdasarkan hasil penelitian dapat diketahui bahwa ada peningkatan hasil belajar siswa. Hasil pembelajaran pada tahap siklus II lebih baik jika dibandingkan dengan pembelajaran pada tahap prasiklus dan siklus I. Hal ini dapat dilihat dari meningkatnya nilai rata-rata siswa. Selain itu kemandirian siswa mulai tampak dan perhatian dalam pembelajaran lebih meningkat daripada pada tahap prasiklus dan siklus I. Hal ini sesuai dengan teori dari Sudjana (2013:45) mengemukakan bahwa setiap proses belajar mengajar keberhasilannya diukur dari seberapa jauh hasil belajar yang dicapai siswa, disamping diukur dari segi prosesnya. Hasil belajar merupakan perubahan perilaku secara keseluruhan bukan hanya salah satu aspek potensi kemanusiaan saja (Suprjono, 2009:7). Menurut Purwanto (2013:46) Hasil belajar pada hakikatnya adalah perubahan perilaku akibat belajar. Perubahan perilaku disebabkan karena dia mencapai penguasaan atas sejumlah bahan yang diberikan dalam proses belajar mengajar. Pencapaian itu didasarkan atas tujuan pengejaran yang telah ditetapkan.

Hewitt (2008: 35) secara singkat juga menjelaskan bahwa "Learning is an active process of constructing knowledge." Belajar merupakan sebuah proses aktivitas dalam mengontruksi pengetahuan. Pernyataan di atas memandang belajar sebagai suatu proses pemahaman informasi baru berupa penyusunan pengetahuan yang terus-menerus melalui interpretasi pengalamanpengalaman konkret dengan membangun/mengonstruksi berdasarkan pengetahuan sebelumnya.

Hasil observasi aktivitas guru dari siklus I hingga siklus II terjadi peningkatan yang positif, dari kriteria cukup meningkat menjadi baik. Ini menggambarkan bahwa kesiapan guru dalam menggunakan model pembelajaran examples non examples berbantuan media gambar berhasil baik, karena guru sudah bisa beradaptasi dengan model pembelajaran examples non examples berbantuan media gambar yang digunakan dalam pembelajaran.

Hasil observasi aktivitas guru pada siklus I dan siklus II dapat dilihat pada tabel dan diagram berikut. 
Tabel 2 Perbandingan Aktivitas Guru Siklus I dan siklus II

\begin{tabular}{|l|c|c|}
\hline \multicolumn{1}{|c|}{ Kegiatan } & Siklus I & Sikus II \\
\hline Skor Maksimal & 60 & 60 \\
\hline Skor Perolehan & 34 & 46 \\
\hline Persentase & $56,6 \%$ & $76,6 \%$ \\
\hline
\end{tabular}

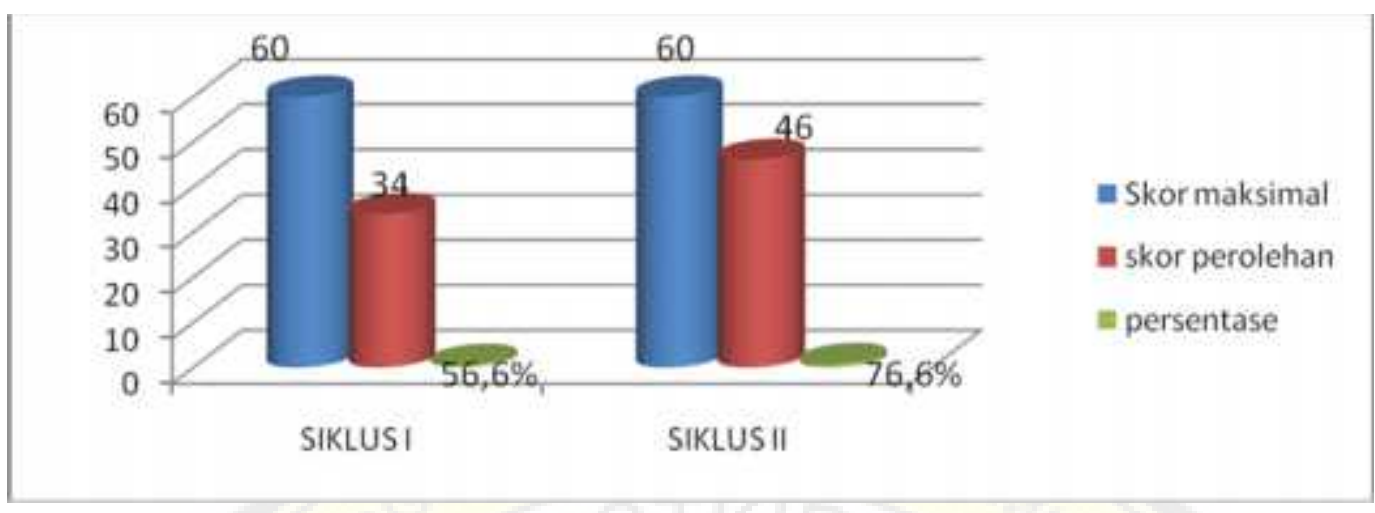

Diagram 2 Perbandingan Aktivitas Guru pada Siklus I dan Siklus II

Lingkungan merupakan sumber informasi alamiah yang sangat kaya. Oleh karena itu, pemanfaatan objek yang ada di lingkungan sebagai materi, media, dan sumber belajar dalam perencanaan pembelajaran menulis deskripsi dapat dilakukan. Pada perencanaan pembelajaran menulis deskripsi dengan model pembelajaran examples non examples berbantuan media gambar, media utama yang digunakan adalah media gambar atau objek yang ada di lingkungan sekitar secara langsung. Lingkungan merupakan salah satu faktor penting dalam pembentukan pengetahuan siswa. Siswa membutuhkan lingkungan dalam bereksplorasi dan melakukan kegiatan fisik untuk mencapai kesiapan akademiknya dalam belajar. Selain penggunaan media yang berupa objek yang ada di lingkungan, pada perencanaan juga dirumuskan penggunaan media lain, yaitu gambargambar yang bertemakan lingkungan, bacaan pendek tentang lingkungan, model-model teks, dan lembar kerja siswa (LKS). Pentingnya media dalam sebuah pembelajaran, terutama media yang berupa objek yang nyata sejalan dengan pendapat Anderson. Anderson (1987:183) menyatakan bahwa objek yang sesungguhnya, atau benda model yang mirip sekali dengan benda nyatanya, akan memberikan rangsangan yang amat penting bagi siswa dalam mempelajari tugas yang menyangkut keterampilan psikomotorik.

\section{SIMPULAN DAN SARAN}

\section{Simpulan}

Penggunaan model pembelajaran examples non examples berbantuan media gambar dapat meningkatkan pencapaian hasil belajar siswa, pada siklus I dengan nilai rata-rata 69,70 dan 
ketuntasan klasikal $50 \%$ mengalami peningkatan pada siklus II dengan nilai rata-rata 76,76 dengan ketuntasan klasikal 82,35\%.

Aktivitas guru dan siswa terhadap pembelajaran bahasa dengan penggunaan model pembelajaran examples non examples berbantuan media gambar juga menunjukkan peningkatan. Hal ini dapat diihat dari perolehan nilai aktivitas belajar siswa, pada siklus I dengan rata-rata 58,75 dalam kategori kurang aktif mengalami peningkatan pada siklus II dengan rata-rata 82,5 dalam kategori aktif. Begitupun dengan aktivitas guru yang dilihat dari hasil observasi pada siklus I dengan persentase 56,6 \% dalam kategori cukup meningkat pada siklus II dengan persentase 76,6\% dalam kategori baik.

Hasil respon siswa terhadap pembelajaran yang disajikan guru dari hasil angket yang dijawab siswa menunjukkan bahwa siswa menyenangi dan sangat termotivasi terhadap model pembelajaran examples non examples berbantuan media gambardalam pembelajaran bahasa.

\section{Saran}

Hendaknya para guru, khususnya guru bahasa Indonesia memiliki kreativitas dan inovasi, khususnya dalam hal penggunaan model pembelajaran. Salah satunya ialah model pembelajaran examples non examples berbantuan media gambar yang sangat membantu meningkatkan keterampilan menulis siswa, serta memotivasi siswa mengikuti pembelajaran yang disajikan, sehingga dapat meningkatkan prestasi belajar siswa pada pembelajaran bahasa Indonesia. Pilihlah materi yang sesuai dengan strategi yang akan digunakan, karena kesalahan dalam pemilihan strategi pembelajaran akan berdampak menurunnya minat siswa dalam belajar.

Bagi siswa diharapkan agar lebih aktif dan kreatif dalam proses pembelajaran sehingga dapat meningkatkan hasil belajar, khususnya materi pembelajaran menulis.

Kepada pihak sekolah diharapkan dapat mengupayakan ketersediaan sarana sebagai salah satu penunjang keberhasilan pengajaran bahasa Indonesia. Oleh karena itu buku pelajaran, alat dan media dalam proses belajar mengajar sangat diperlukan sehingga tujuan yang diharapkan dapat tercapai secara optimal.

\section{Daftar Pustaka}

Arikunto, Suharsimi, dkk. 2010. Penelitian Tindakan Kelas. Jakarta: Rineka Cipta.

Daryanto. 2009. Panduan Proses Pembelajaran Kreatif \& Inovatif. Jakarta: Publisher.

Depdiknas. 2006. Silabus Mata Pelajaran Matematika. Tingkat SD/MI. Jakarta: Depdiknas

Gipayana, Muhana. 2006. Metode Penelitian Bahasa. Bandung: Rosda.

Poerwanti, Endang, Widodo, Masduki, Pantiwati, Rofiek, Utumo. 2009. Assesmen Pembelajaran di $S D$. Direktorat Jenderal Pendidikan Tinggi: Departemen Pendidikan Nasional. 
Purwanto. 2013. Evaluasi Hasil Belajar. Yogyakarta: Pustaka Pelajar.

Sardiman, Arief. S, dkk. 2011. Media Pendidikan:Pengertian, Pengembangan, dan Pemanfaatannya. Jakarta: PT Raja Grafindo Persada.

Soekamto, dkk. 2009. Panduan E-Tugas Akhir. Depdiknas.

Sanjaya, Wina. 2010. Strategi Pembelajaran Berorientasi Standar Proses Pendidikan. Jakarta: Kencana.

Suprijono, Agus. 2009. Cooperative Learning: Teori dan Aplikasi PAIKEM. Surabaya: Pustaka Pelajar.

Suyatno. 2009. Menjelajah Pembelajaran Inovatif. Sidoarjo: Masmedia Buana. 